\title{
Antibiotic Susceptibility of Bacteria Isolated from Open Fracture Grade III Presenting to Dr. Soetomo General Hospital Surabaya
}

\author{
Raden Taufan Mulyo Wibisono ${ }^{1}$, Dwikora Novembri Utomo ${ }^{1}$ iD, Agung Dwi Wahyu Widodo ${ }^{2}$ \\ ${ }^{1}$ Department of Orthopedic and Traumatology, Faculty of Medicine, Airlangga University/Dr. Soetomo General \\ Hospital, Surabaya, Indonesia \\ ${ }^{2}$ Department of Clinical Microbiology, School of Medicine, Airlangga University/Dr. Soetomo General Hospital, \\ Surabaya, Indonesia
}

Correspondence should be addressed to Raden Taufan Mulyo Wibisono, Department of Orthopedic and Traumatology, Faculty of Medicine, Universitas Airlangga, Jl. Mayjen Prof. Dr. Moestopo No. 6-8, Surabaya 60286, Indonesia. e-mail: rtmortho@gmail.com

\begin{abstract}
Background: Open fracture is a typical case in the orthopedics field. Infection in the open fracture can cause osteomyelitis. Antibiotic susceptibility test of patient specimen bacteria with open fracture aims to obtain the suitable antibiotic agents to treat infectious diseases caused by these bacteria.

Methods: This research is a descriptive study to assess Antibiotic susceptibility in the case of open fracture grade III in Dr. Soetomo General Hospital Surabaya. A total sampling was performed from microbiological culture results of patients diagnosed with open fracture grade III after debridement from October 2018 to September 2019. The identification of the microbes was based on Gram-positive and Gram-negative categories and the classification based on susceptibility to antibiotics classified into sensitive, intermediate, and resistant.

Results: Data from microbiological culture results of patients with a diagnosis of open fracture grade III after debridement in October 2018 to September 2019 in Dr. Soetomo General Hospital Surabaya showed 56 research subjects who met the criteria. Acinetobacter baumannii is the most common bacterial species found in the microbiological examination of patients with open fractures, $15.84 \%$. Cefazoline and ceftriaxone showed low susceptibility. Meanwhile, levofloxacin showed a relatively good value of susceptibility in both Gram-positive and negative bacterial groups.

Conclusion: The antibiotic susceptibility pattern of bacteria from specimens in open fracture grade III patients in Dr. Soetomo General Hospital Surabaya varies between each species of bacteria isolate.
\end{abstract}

Keywords: Open fracture; Grade III; Antibiotics; Susceptibility; Human and Medicine

\section{INTRODUCTION}

Osteomyelitis is challenging to eradicate and requires a long treatment period and will significantly impact function, quality of life, financial, and psychosocial. ${ }^{1}$ The number of post-debridement bacterial colonies significantly affects the risk of infection in an open fracture. ${ }^{2}$ Therefore, it is necessary to reduce the number of bacterial colonies in open fractures. One of the therapies to achieve this is by debriding and providing effective antibiotic therapy. ${ }^{3}$ 
The hospital must have a bacterial susceptibility pattern as a reference for effective antibiotics and prevent irrational antibiotic therapy. ${ }^{4}$ This study aims to obtain data on the bacterial susceptibility pattern in open fracture cases at Dr. Soetomo General Hospital Surabaya, so it is hoped that it can become a reference for providing rational and adequate antibiotic therapy in open fracture cases.

\section{MATERIAL AND METHODS}

This study was approved by Dr. Soetomo General Hospital Surabaya Ethical Committee. This research is a descriptive study regarding bacterial susceptibility patterns in open fracture III degrees at Dr. Soetomo General Hospital Surabaya. This study's sampling technique was a total sampling of bacterial data from microbiological cultures of patients diagnosed with post debridement grade III open fracture in the period from October 2018 to September 2019 at Dr. Soetomo General Hospital Surabaya.

The inclusion criteria of this research are 1. Patients who were diagnosed with grade III open fracture includes humerus, radius, ulna, femur, tibia, fibula, clavicle, scapula, spine, pelvis, carpal, patella, metacarpal, phalanx, talus, calcaneus, tarsal, and metatarsal; 2) Patients underwent debridement; 3) The specimen from the patient underwent microbiological culture. Exclusion criteria were: 1) Patients diagnosed with grade III open fracture include the skull, ribs, vertebrae;
2) Patients underwent debridement surgery in a hospital outside Dr. Soetomo General Hospital Surabaya.

The microbiological cultures are classified into Gram-positive and Gram-negative bacteria. $^{5}$ The antibiotic susceptibility determines the response of bacterial to an antibiotic at a concentration level that can inhibit/kill bacterial. The results are divided into sensitive, intermediate, and resistant. ${ }^{6}$ After classifying bacterial based on Grampositive and Gram-negative categories followed by bacterial classification based on susceptibility to antibiotics. The analysis is carried out to obtain a profile of bacterial susceptibility in patients with open fracture degree III at Dr. Soetomo General Hospital Surabaya.

\section{RESULTS}

Fifty-six subjects met the inclusion criteria and did not meet the exclusion criteria. Based on Table 1, most open fracture sufferers are aged 11-30 years $(46.40 \%)$. The male gender group had a higher number than female, namely 39 subjects or $69.7 \%$. The most common open fractures location was in the lower leg region in 22 cases, or $39.29 \%$. Meanwhile, the number of open fracture cases in the forearm and foot regions had a similar value, namely 8 cases or $14.29 \%$.

In Table 2, the distribution of bacteria shows that Acinetobacter baumannii is the most common species of bacteria found on the microbiological examination of open fracture 
sufferers, which is $15.84 \%$. In comparison, $E$. Coli ESBL is the pathogen with the second largest number of $11.88 \%$. Meanwhile, other pathogens found from isolated cultures can be seen in the table below. An overview of the pattern of bacterial susceptibility to various kinds of antibiotics can be seen in more detail in the table below, shown in Table 3 and 4 . This test results show that the susceptibility value varies based on the bacteria species and the kinds of antibiotics used.

Table 1. Subject Characteristics

\begin{tabular}{lcc}
\hline & $\begin{array}{c}\text { Total } \\
(\mathbf{n = 5 6})\end{array}$ & $\begin{array}{c}\text { Percentage } \\
(\mathbf{\%})\end{array}$ \\
\hline Age & & \\
11-30 years & 26 & 46.40 \\
31-50 years & 20 & 35.70 \\
$\quad>$ 50 years & 10 & 17.90 \\
Gender & & \\
$\quad$ Male & 39 & 69.7 \\
$\quad$ Women & 17 & 30.3 \\
Fracture Location & & \\
$\quad$ Forearm & 8 & 14.29 \\
$\quad$ Thigh & 18 & 32.14 \\
$\quad$ Lower leg & 22 & 39.29 \\
$\quad$ Foot & 8 & 14.29 \\
\hline
\end{tabular}

\section{DISCUSSION}

Open fracture type IIIB is associated with extensive injury or soft tissue loss, accompanied by periosteal stripping and bone exposure, massive contamination, and a severe degree of comminution. ${ }^{7}$ Based on the results of the characteristics of the research subjects, it appears that the majority of open fracture sufferers are between 11-30 years old (46.40\%). Several studies reported by Arti et al and Courtbrown et al expressed mean age at $23 \pm 1.5$ years and 29.5 years, respectively. It is because this age group have activities or activities that are more prone to serious injury than other age groups. ${ }^{8,9}$

Table 2. Distribution of Bacteria based on Microbiological Examination

\begin{tabular}{|c|c|c|}
\hline & $\begin{array}{c}\text { Total } \\
(\mathbf{n}=\mathbf{1 0 1})\end{array}$ & $\begin{array}{c}\text { Percentage } \\
(\%)\end{array}$ \\
\hline \multicolumn{3}{|l|}{ Bacteria } \\
\hline $\begin{array}{l}\text { Acinetobacter } \\
\text { baumannii }\end{array}$ & 16 & 15.84 \\
\hline E. coli ESBL & 12 & 11.88 \\
\hline $\begin{array}{l}\text { Pseudomonas } \\
\text { aeruginosa }\end{array}$ & 10 & 9.90 \\
\hline Proteus mirabilis & 9 & 8.91 \\
\hline Enterobacter cloacae & 7 & 6.93 \\
\hline Providencia stuartii & 6 & 5.94 \\
\hline$M R S A$ & 5 & 4.95 \\
\hline Staphylococcus aureus & 5 & 4.95 \\
\hline Morganella morganii & 3 & 2.97 \\
\hline Globicatella sanguinis & 2 & 1.98 \\
\hline Enterococcus faecalis & 2 & 1.98 \\
\hline Bacillus cereus & 2 & 1.98 \\
\hline $\begin{array}{l}\text { Corynebacterium } \\
\text { striatum }\end{array}$ & 2 & 1.98 \\
\hline $\begin{array}{l}\text { Staphylococcus } \\
\text { epidermidis }\end{array}$ & 2 & 1.98 \\
\hline $\begin{array}{l}\text { Enterobacter } \\
\text { aerogenes }\end{array}$ & 2 & 1.98 \\
\hline Streptococcus gordonii & 2 & 1.98 \\
\hline Gemella haemolysans & 1 & 0.99 \\
\hline Pantoea agglomerans & 1 & 0.99 \\
\hline $\begin{array}{l}\text { Candida Parapsilosis } \\
\text { this is fungi, not } \\
\text { bacteria }\end{array}$ & 1 & 0.99 \\
\hline Enterococcus faecalis & 1 & 0.99 \\
\hline $\begin{array}{l}\text { Klebsiella pneumoniae } \\
\text { ESBL }\end{array}$ & 1 & 0.99 \\
\hline $\begin{array}{l}\text { Staphylococcus } \\
\text { schleiferi }\end{array}$ & 1 & 0.99 \\
\hline E. coli & 1 & 0.99 \\
\hline Aeromonas hydrophila & 1 & 0.99 \\
\hline Providencia rettgeri & 1 & 0.99 \\
\hline Amycolatum striatum & 1 & 0.99 \\
\hline Kluyvera ascorbata & 1 & 0.99 \\
\hline $\begin{array}{l}\text { Stenotrophomonas } \\
\text { maltophilia }\end{array}$ & 1 & 0.99 \\
\hline $\begin{array}{l}\text { Streptococcus } \\
\text { anginosus }\end{array}$ & 1 & 0.99 \\
\hline Ralstonia pickettii & 1 & 0.99 \\
\hline
\end{tabular}


Table 3. Antibiotic Susceptibility to Gram-positive Bacteria

\begin{tabular}{|c|c|c|c|c|c|c|c|c|c|c|c|c|}
\hline & 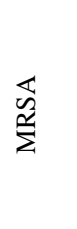 & 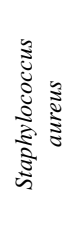 & 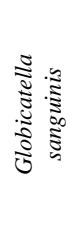 & 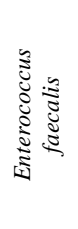 & 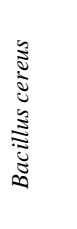 & 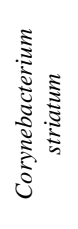 & 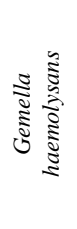 & 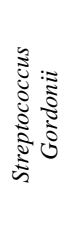 & 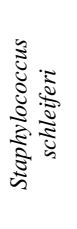 & 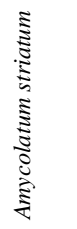 & 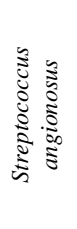 & 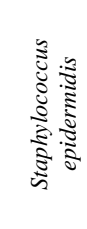 \\
\hline & \multicolumn{12}{|c|}{ The number of bacteria tested(percentage) } \\
\hline Amikacin & - & $5(100)$ & 0 & 0 & - & 0 & - & - & $1(100)$ & $1(100)$ & - & - \\
\hline Gentamicin & 0 & $4(80)$ & 0 & 0 & $2(100)$ & - & 0 & - & $1(100)$ & $1(100)$ & 0 & $1(100)$ \\
\hline Aztreonam & - & - & - & - & - & - & - & - & - & - & - & - \\
\hline $\begin{array}{l}\text { Amoxicillin- } \\
\text { Clavulanic Acid }\end{array}$ & 0 & $4(80)$ & $2(100)$ & $2(100)$ & - & 0 & - & - & 0 & - & - & $1(100)$ \\
\hline Ampicillin & 0 & 0 & - & $1(50)$ & 0 & - & - & 0 & 0 & - & $1(100)$ & 0 \\
\hline $\begin{array}{l}\text { Ampicillin- } \\
\text { sulbactam }\end{array}$ & - & - & - & - & 0 & - & - & - & - & - & - & - \\
\hline Piperacillin & - & - & - & - & - & - & - & - & - & - & - & - \\
\hline Tazobactam & - & - & - & $2(100)$ & $2(100)$ & 0 & - & - & - & $1(100)$ & $1(100)$ & $1(100)$ \\
\hline Oxacillin & 0 & $4(80)$ & - & 0 & 0 & - & - & - & 0 & 0 & - & $1(100)$ \\
\hline Cefazolin & - & - & - & - & - & - & - & - & - & - & - & - \\
\hline Ceftazidime & - & - & - & - & - & - & - & - & - & - & - & - \\
\hline Cefotaxime & 0 & - & - & 0 & - & 0 & 0 & 0 & - & - & 0 & - \\
\hline Ceftriaxone & - & - & - & 0 & - & 0 & 0 & $2(100)$ & - & - & $1(100)$ & - \\
\hline Cefepime & - & - & - & - & - & - & - & - & - & - & - & - \\
\hline $\begin{array}{l}\text { Trimethoprim- } \\
\text { Sulfamethoxazole }\end{array}$ & $2(40)$ & $5(100)$ & 0 & 0 & 0 & 0 & 0 & 0 & $1(100)$ & 0 & $1(100)$ & $1(100)$ \\
\hline Tetracyclin & $1(20)$ & 0 & - & - & - & - & - & - & 0 & - & 0 & $1(100)$ \\
\hline Tigecycline & - & - & - & - & - & - & - & $2(100)$ & - & - & - & $1(100)$ \\
\hline Chloramphenicol & $2(40)$ & 60 & 0 & $2(100)$ & $1(50)$ & $1(50)$ & 0 & $2(100)$ & - & $1(100)$ & 0 & $1(100)$ \\
\hline Erythromycin & $2(40)$ & $4(80)$ & $1(50)$ & 0 & $1(50)$ & 0 & 0 & $2(100)$ & 0 & 0 & 0 & $1(100)$ \\
\hline Clindamycine & $3(60)$ & $4(80)$ & 0 & 0 & 0 & 0 & 0 & $2(100)$ & 0 & 0 & 0 & 0 \\
\hline $\begin{array}{l}\text { Quinopristin- } \\
\text { dalfopristin }\end{array}$ & $5(100)$ & $5(100)$ & - & 0 & - & - & - & - & - & - & - & - \\
\hline Ciprofloxacin & 0 & $4(80)$ & - & - & - & - & - & - & 100 & - & - & $1(100)$ \\
\hline Levofloxacin & 0 & 75 & $1(50)$ & $2(100)$ & $2(100)$ & 0 & - & $2(100)$ & - & 0 & $1(100)$ & $1(100)$ \\
\hline Moxifloxacin & $2(40)$ & 75 & - & - & - & - & - & $2(100)$ & - & - & - & $1(100)$ \\
\hline Fosfomycin & $5(100)$ & $4(80)$ & - & $2(100)$ & $2(100)$ & $1(50)$ & - & - & - & 0 & 0 & $1(100)$ \\
\hline Nalidixic Acid & - & - & - & - & - & - & - & - & - & - & - & - \\
\hline Imipenem & - & - & - & - & - & - & - & - & - & - & - & - \\
\hline Meropenem & - & - & - & - & - & - & - & - & - & - & - & - \\
\hline Vancomycin & $5(100)$ & $5(100)$ & $1(50)$ & $2(100)$ & 0 & $2(100)$ & $1(100)$ & $2(100)$ & 0 & - & $1(100)$ & $1(100)$ \\
\hline Linezolid & $5(100)$ & $5(100)$ & $1(50)$ & $2(100)$ & $2(100)$ & $2(100)$ & $1(100)$ & $2(100)$ & 0 & - & $1(100)$ & $1(100)$ \\
\hline Fosfomycin & 0 & $5(100)$ & 0 & 0 & - & - & - & - & - & $1(100)$ & - & $1(100)$ \\
\hline
\end{tabular}

The male gender group had a greater number than women, namely 39 subjects or $69.7 \%$. It is explained that men are generally more prone to injury due to exposure to risky activities both at work and in their leisure time. ${ }^{10}$ The most common location of open fractures was in the lower leg region in 22 cases, or $39.29 \%$. Several studies reported the same thing, Kale et al stated $40.62 \%$ and Arti et al, $62 \%$ incidence of open fractures in the lower leg region. ${ }^{8,11}$ Meanwhile, the number of open fracture cases in the forearm and foot regions had a similar value, namely 8 cases or $14.29 \%$.

In the istribution of bacteria, it appears that Acinetobacter baumannii is the most common species of bacteria found in the microbiological examination of infected open fracture patients, which is $15.84 \%$. The same results were reported in a study by Kale et al. 
Table 4. Antibiotic Susceptibility to Gram-negative Bacteria

\begin{tabular}{|c|c|c|c|c|c|c|c|c|c|c|c|c|c|c|c|c|}
\hline & 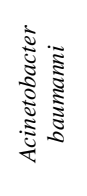 & 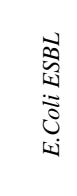 & 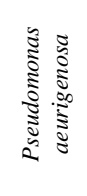 & 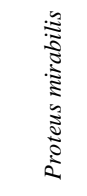 & 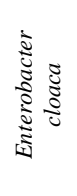 & 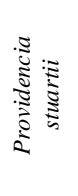 & 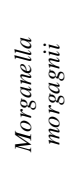 & 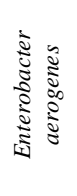 & 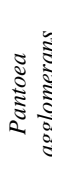 & 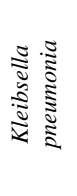 & $\underbrace{\tilde{j}}_{i j}$ & 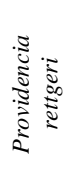 & 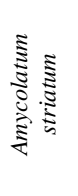 & 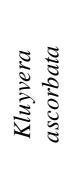 & 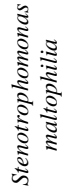 & 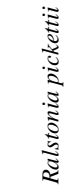 \\
\hline & \multicolumn{16}{|c|}{ The number of bacteria tested(percentage) } \\
\hline Amikacin & 0 & $9(100)$ & $6(60)$ & $9(100)$ & $7(100)$ & $4(67)$ & $3(100)$ & $2(100)$ & 0 & 0 & $1(100)$ & $1(100)$ & $1(100)$ & $1(100)$ & 0 & $1(100)$ \\
\hline Gentamicin & 0 & - & $6(60)$ & $5(55)$ & 2(29) & 0 & $2(67)$ & 50 & 0 & $1(100)$ & - & 0 & $1(100)$ & $1(100)$ & 0 & 0 \\
\hline Aztreonam & 0 & $3(33)$ & $3(30)$ & $8(88)$ & $1(14)$ & 0 & $2(67)$ & 50 & 0 & - & $1(100)$ & 0 & - & 0 & 0 & 0 \\
\hline Amoxicillin/Clavulanic Acid & 0 & - & 0 & $5(55)$ & 0 & 0 & 0 & 0 & 0 & - & 0 & 0 & - & 0 & 0 & 0 \\
\hline Ampicillin & 0 & 0 & 0 & $1(11)$ & 0 & 0 & 0 & 0 & 0 & $1(100)$ & 0 & 0 & - & 0 & 0 & 0 \\
\hline Ampicillin-sulbactam & 0 & $2(22)$ & 0 & $5(55)$ & 0 & $1(17)$ & 0 & 0 & 0 & - & 0 & 0 & - & 0 & 0 & 0 \\
\hline Piperacillin & 0 & 0 & $8(80)$ & $5(55)$ & $1(14)$ & 0 & - & $2(100)$ & 0 & - & 0 & 0 & - & 0 & 0 & 0 \\
\hline Tazobactam & 0 & 8 & $8(80)$ & $7(77)$ & $3(43)$ & $5(83)$ & $3(100)$ & $2(100)$ & 0 & - & $1(100)$ & 0 & $1(100)$ & 0 & 0 & $1(100)$ \\
\hline Oxacillin & - & - & - & - & - & - & - & - & - & 0 & - & - & 0 & - & - & - \\
\hline Cefazolin & 0 & 0 & 0 & $6(67)$ & 0 & 0 & 0 & 0 & 0 & - & 0 & 0 & - & 0 & 0 & 0 \\
\hline Ceftazidime & 0 & $8(88)$ & $8(80)$ & $9(100)$ & $1(14)$ & 0 & $3(100)$ & $1(50)$ & 0 & - & $1(100)$ & 0 & - & 0 & 0 & 0 \\
\hline Cefotaxime & 0 & - & $1(10)$ & $5(55)$ & $1(14)$ & 0 & $1(33)$ & $1(50)$ & 0 & - & $1(100)$ & 0 & - & 0 & 0 & 0 \\
\hline Ceftriaxone & 0 & - & $2(20)$ & $7(77)$ & $1(14)$ & 0 & 1(33) & $1(50)$ & 0 & - & $1(100)$ & 0 & - & 0 & 0 & $1(100)$ \\
\hline Cefepime & 0 & 0 & $4(40)$ & $7(77)$ & $4(57)$ & 0 & $1(33)$ & $2(100)$ & 0 & - & $1(100)$ & 0 & - & $1(100)$ & - & 0 \\
\hline Trimethoprim/Sulfamethoxazole & $2(13)$ & - & 0 & $1(11)$ & $3(43)$ & 0 & $1(33)$ & $1(50)$ & 0 & 0 & $1(100)$ & $1(100)$ & 0 & $1(100)$ & $1(100)$ & 0 \\
\hline Tetracyclin & 0 & 0 & 0 & 0 & $5(71)$ & 0 & 0 & $2(100)$ & 0 & - & 0 & 0 & - & $1(100)$ & 0 & - \\
\hline Tigecycline & $4(25)$ & 0 & 0 & $4(44)$ & $4(57)$ & $6(100)$ & 0 & - & 0 & - & $1(100)$ & 0 & - & - & $1(100)$ & - \\
\hline Chloramphenicol & 0 & 0 & 0 & $1(11)$ & 2(29) & 0 & 0 & $1(50)$ & 0 & - & - & 0 & $1(100)$ & $1(100)$ & 0 & 0 \\
\hline Erythromycin & - & - & - & - & - & - & - & - & - & 0 & $1(100)$ & - & 0 & - & - & - \\
\hline Clindamycin & - & $9(100)$ & - & - & - & - & - & - & - & 0 & - & - & 0 & - & - & - \\
\hline Quinopristin-dalfopristin & - & - & $10(100)$ & - & - & - & - & - & - & $1(100)$ & - & - & - & - & - & - \\
\hline Ciprofloxacin & 0 & 0 & $3(30)$ & $4(44)$ & $1(14)$ & $5(83)$ & $2(67)$ & $2(100)$ & 0 & - & $1(100)$ & 0 & - & $1(100)$ & - & 0 \\
\hline Levofloxacin & 0 & $2(22)$ & $6(60)$ & $4(44)$ & $4(57)$ & $3(50)$ & $1(33)$ & $1(50)$ & 0 & $1(100)$ & $1(100)$ & 0 & 0 & $1(100)$ & 0 & 0 \\
\hline Moxifloxacin & - & - & - & $3(33)$ & 2(29) & $2(33)$ & $1(33)$ & $2(100)$ & 0 & - & $1(100)$ & 0 & - & $1(100)$ & - & - \\
\hline Fosfomycin & 0 & $3(33)$ & $3(30)$ & $5(55)$ & $4(57)$ & 0 & 0 & 0 & - & - & $1(100)$ & 0 & 0 & $1(100)$ & 0 & 0 \\
\hline Nalidixic Acid & - & $5(55)$ & - & - & - & - & - & - & - & - & - & - & - & - & - & - \\
\hline Imipenem & 0 & $5(55)$ & $6(60)$ & - & $6(86)$ & - & - & 0 & 0 & - & $1(100)$ & 0 & - & $1(100)$ & 0 & 0 \\
\hline Meropenem & 0 & - & $7(70)$ & $9(100)$ & $7(100)$ & $5(83)$ & $3(100)$ & $2(100)$ & 0 & - & $1(100)$ & 0 & - & $1(100)$ & 0 & $1(100)$ \\
\hline Vancomycin & - & - & $10(100)$ & - & - & - & - & - & - & $1(100)$ & - & - & - & - & - & - \\
\hline Linezolid & - & - & $10(100)$ & - & - & - & - & - & - & - & - & - & - & - & - & - \\
\hline Fosfomycin & 0 & 27 & 0 & 100 & 100 & - & - & - & - & 0 & - & - & $1(100)$ & - & - & - \\
\hline
\end{tabular}

It was stated that the bacteria often found in open fractures is Acinetobacter baumannii, $14.06 \%$ of all swab culture results. ${ }^{11}$

Another study by Zhu et al in 337 cases of an open fracture shows that the isolation of Acinetobacter baumannii culture was found in 16 cases out of 201 cases contaminated with seawater. Based on the research results described above, it appears that Acinetobacter baumannii, as the species of pathogen most often found in culture isolations of patients with open fracture grade III post debridement, showed low susceptibility to the kinds of antibiotics tested. On examination, susceptibility was found to 2 kinds of antibiotics, namely TrimethoprimSulfamethoxazole (13\%) and Tigecycline (22\%). The genus Acinetobacter includes nonlactose-fermenting, catalase-positive, nonmotile, non-fastidious, oxidase-negative, and aerobic Gram-negative coccobacilli. 
Acinetobacter baumannii is clinically significant because it involves nosocomial infections and intrinsically resistant to wider classes of antimicrobials with a high propensity to develop resistance. It is caused by the unique ability of Acinetobacter baumannii to survive desiccation, renders its viability in inanimate objects for months, and thus facilitates its spread in the hospital. ${ }^{12,13}$ Acinetobacter species are capable of accumulating multiple antibiotic resistance genes, leading to the development of multidrug-resistant or extensively drugresistant strains through the production of $\beta$ lactamases, efflux pumps, lower permeability of the outer membrane, mutations in antibiotic targets (e.g., for quinolones), production of enzymes inactivating aminoglycosides. ${ }^{14-16}$

The first line antibiotics for infection caused by Acinetobacter baumannii including a broad-spectrum cephalosporin (ceftazidime or cefepime), a combination beta-lactam/betalactamase inhibitor (i.e., one that includes sulbactam), or a carbapenem (e.g., imipenem, meropenem, or doripenem). Carbapenems are highly bactericidal against susceptible strains of Acinetobacter, but isolates that are susceptible to imipenem may be resistant to meropenem, and vice versa, susceptibility to the specific carbapenem should be confirmed before its use. ${ }^{16}$ Acinetobacter baumannii that resistance to the above agents have limited therapeutic options, certain Tetracyclines (Minocycline and Tigecycline) may also have a role, Polymyxins (Polymyxin B and colistin [polymyxin E]) are the most commonly used agents for
Acinetobacter isolates resistant to first-line agents. ${ }^{16,17}$

E. coli ESBL the second most common bacteria found in isolates of patient specimens with open grade III fractures, namely $11.88 \%$. It is not much different from the findings in the study by Abraham and Wamisho, which showed a total of 17 cases $(10.5 \%)$ of patients with E. coli isolates. E. coli obtained in this study are ESBL-producing bacteria. Extended Spectrum $\beta$-Lactamase (ESBL) is a plasmid enzyme that mediates the hydrolysis and inactivation of beta-lactam antibiotics including third-generation Cephalosporins, Penicillin, and Aztreonam. ${ }^{18}$ In this study, several kinds of antibiotics showed susceptibility values of up to 100\%, namely Ampicillin, Amoxicillinclavulanic acid, Amoxicillin, and Trimethoprim-Sulphamethoxazole. ${ }^{19}$ In this study, results have obtained $100 \%$ susceptibility in the test against the antibiotic Amikacin and Clindamycin.

Pseudomonas aeurigenosa is the third most common bacteria isolated in this study, with a percentage of $9.90 \%$. Pseudomonas aeruginosa is a gram-negative bacillus found widely in nature, soil, and water. Pseudomonas aeruginosa infrequently found as part of the human microflora in healthy individuals is a gram-negative, non-glucose fermenter rod. Pseudomonas aeruginosa is widespread in natural environments, and it is an opportunistic pathogen for humans, leading to a broad spectrum of diseases such as urinary, burn, respiratory infections, and septicemia. ${ }^{20}$ It is the primary cause of ventilated, associated 
pneumonia in the intensive care unit. ${ }^{21}$ In recent years, nosocomial infections caused by Pseudomonas aeruginosa have been recognized as an acute problem in hospitals due to its intrinsic resistance to many antibiotic classes and its capacity to acquire practical resistance to all effective antibiotics. ${ }^{22}$ All these features in Pseudomonas aeruginosa characterize it as a major microorganism to monitor antibiotic resistance in the clinical specimens. On the other hand, the spread of these bacteria in hospital personnel, wet places could be a reservoir. Therefore, it is necessary to evaluate the contribution of hospital equipment and personnel in the dissemination route of multidrug resistance Pseudomonas aeruginosa. $^{23}$

The choices for treatment for Pseudomonas aeruginosa infections include the following antimicrobial agents, with the fluoroquinolones being the only oral options: Aminoglycosides, Cephalosporins, thirdgeneration, Cephalosporins fourth-generation, Fluoroquinolones, Monobactam, Extendedspectrum penicillins (Ticarcillin and/or Ticarcillin-Clavulanate, Piperacillin and/or Piperacillin-Tazobactam,

Azlocillin), Polymyxin B/Colistin. In systemic infection with shock/sepsis, antimicrobial therapy should consist of two intravenous antimicrobial agents, with one of these being an aminoglycoside. ${ }^{24}$

\section{Acinetobacter baumannii, E. Coli} ESBL, and Pseudomonas aeruginosa are nosocomial bacterial that is often found in intensive care unit environments. ${ }^{25}$ In Dr. Soetomo General Hospital Surabaya, all patients with open fractures who underwent emergency surgery will be admitted to the intensive care unit for postoperative observation. That procedure could contribute to why Acinetobacter baumannii, E. Coli ESBL, and Pseudomonas aeruginosa are the most species found in this study.

Several studies reported different things; the most common bacteria found were Pseudomonas aeruginosa and Staphylococcus capitis. ${ }^{26,27}$ In a prospective study of infection in open fractures, $78.7 \%$ of all open fractures were contaminated with bacteria. The rate of infection correlated directly with the fracture type, according to Gustillo et al, $24.5 \%$ in type I open fractures and $86.8 \%$ in type IIIC open fractures. Infection is usually caused by various bacteria dominated by Staphylococcus aureus (52.8\%), E. coli and Enterobacter (32.5\%), Streptococcus (26.0\%), Pseudomonas (17.1\%) and Proteus $(1.6 \%) .{ }^{28}$

Based on the average antibiotic susceptibility for the top 5 most common Grampositive bacteria, the most effective antibiotic includes Linezolid, Vancomycin, Levofloxacin, Chloramphenicol Erythromycin, respectively. Meanwhile, the most effective antibiotic for Gram-negative bacteria includes Meropenem, Amikacin, Tazobactam, Tigecycline, and Levofloxacin.

The use of Cefazolin as an antibiotic in grade III open fractures shows a low susceptibility value in this study, its difference with the study by Patanwala et al showed that Cefazolin monotherapy in cases of grade III 
open fractures was as effective as the use of Cefazolin with Aminoglycosides in the incidence of infection at the fracture site with a lower risk of kidney problems. ${ }^{29-32}$

Meanwhile, the evaluation of ceftriaxone's susceptibility as a recommended antibiotic for grade III open fracture cases at Dr. Soetomo General Hospital Surabaya showed different susceptibility values, namely $22 \%$ (Pseudomonas aeruginosa) and $100 \%$ (E. Coli). Research by Abraham and Wamisho showed an excellent susceptibility value to the use of ceftriaxone in open fracture cases with various degrees, namely between 66.7 to $100 \%$ in different species of bacterial isolates. ${ }^{19}$

In this study, the most bacteria isolated were nosocomial bacteria which were multiresistant bacterial. Hence infection control measures to prevent nosocomial infections are essential. Infection measure control including hand-hygiene protocols, routine cultures from healthcare personnel and environment, identification of environmental sites serving as common sources of transmission, closure of hospital units/wards for sterilization, disinfection of potentially contaminated medical equipment, use of individual medical equipment, minimize time on intensive care unit after post-emergency surgery on open fracture patient.

\section{CONCLUSION}

The rational use of antibiotics and supported by the selection of antibiotics based on culture and antibiotic susceptibility tests and the prevention of nosocomial infection are the main pillars in preventing grade III open fracture complications.

\section{REFERENCES}

1. Ivan F. Rubel; Sean Lager. The Socioeconomic Impact of Chronic Osteomyelitis: The Most Frequent Complication. Orthopaedic Trauma Association. 2004:67.

2. Tornetta P, Rocca GJ, Morshed S, Jones C, Heels-Ansdell D, Sprague S et al. Risk Factors Associated with Infection in Open Fractures of the Upper and Lower Extremities. J Am Acad Orthop Surg Glob Res Rev. 2020; 4(12): e20.00188.

3. Ryan SP, Pugliano V. Controversies in Initial Management of Open Fractures. Scand J of Surg. 2013;103:132-137.

4. Ahmend I, Zafar H, Lakhnana NK, Ishtiaq S. Hospital Antibiogram: A Necessity in Monitoring Sensitivity of Isolates and Rationale Use of Antibiotics. Microbiol Res J Int. 2016; 13(3): 1-8.

5. Sisay M, Worku T, Edessa D. Microbial epidemiology and antimicrobial resistance patterns of wound infection in Ethiopia: A meta-analysis of laboratory-based crosssectional studies. BMC Pharmacol Toxicol. 2019;20(1):1-19.

6. Khan ZA, Siddiqui MF, Park S. Current and Emerging Methods of Antibiotic Susceptibility Testing. Diagnostics (Basel). 2019;9(2):49. Published 2019 May 3.

7. Blom A, Warwick D, Whitehouse MR. Apley and Solomon's System of Orthopaedics and Trauma; 2018.

8. Arti HR. Comparison of early versus delayed debridement in open fractures. Pakistan J Med Sci. 2012; 28(5): 856-859.

9. Court-brown CM, Bugler KE, Clement ND, Duckworth AD, Mcqueen MM. The epidemiology of open fractures in adults . A 15-year review. Injury. 2012; 43(6): 891-897.

10. Odatuwa-Omagbemi DO. Open fractures: Epidemiological pattern, initial management and challenges in a sub-urban teaching hospital in Nigeria. Pan Afr Med J. 2019;33:1-8.

11. Kale AR, Sonawane CS, Waghmare VU, 
Kalambe H. Open Fractures and Incidence of Infection in Tertiary Care Government Hospital. Int J of Sci Study. 2017; 5(403): 24-28.

12. Neidell MJ, Cohen B, Furuya Y, Hill J, Jeon CY, Glied S, et al. Costs of Healthcare- and Community- Associated Infections with Antimicrobial- Resistant Versus Antimicrobial-Susceptible Organisms. Clin Infect Dis. 2012; 55: 807815.

13. Lautenbach E, Synnestvedt M, Weiner MG, Bilker WB, Vo L, Schein J, et al. Epidemiology and Impact of Imipenem Resistance in Acinetobacter baumannii. Infect Control Hosp Epidemiol. 2014; 30(12).

14. Hsueh P, Teng L, Chen C, Chen W. Pandrug-Resistant Acinetobacter baumannii Causing Nosocomial Infections in a University Hospital, Taiwan. Emerg Infect Dis. 2002; 8(8):827-832.

15. Jiang M, Liu L,Ma Y, Zhang Z, Li N, Zhang F, et al. Molecular Epidemiology of Multidrug-Resistant Acinetobacter baumannii Isolated in Shanding, China. Front Microbiol. 2016;7.

16. Fishbain J, Peleg AY. Treatment of Acinetobacter Infections. Clin Infect Dis 2010; 51(1):79-84.

17. Karageorgopoulos DE, Falagas ME. Current control and treatment of multidrug-resistant Acinetobacter baumannii infections. Lancet Infect Dis. 2019; 8(12):751-762.

18. Jang J, Hur HG, Sadowsky MJ, Byappanahalli $\mathrm{MN}$, Yan $\mathrm{T}$, Ishii $\mathrm{S}$. Environmental Escherichia coli: ecology and public health implications-a review. J Appl Microbiol. 2017; 123(3):570-581.

19. Abraham Y, Wamisho BL. Microbial susceptibility of bacteria isolated from open fracture wounds presenting to the err of black-lion hospital, Addis Ababa University, Ethiopia. African J Microbiol Res. 2009; 3(12):939-951.

20. Yang L, Jelsbak L, Lykke R, Damkiær S, Workman CT, Holm M. Evolutionary dynamics of bacteria in a human host environment. Proc Natl Acad Sci USA. 2011; 108(18):7481-7486.

21. Nseir S, Ader F, Lubret R, Marquette C. Pathophysiology of Airway Colonization in Critically ill COPD Patient. Current Drug Targets. 2011:514-520.
22. Fuentefria DB, Ferreira AE, Corção G. Antibiotic-resistant Pseudomonas aeruginosa from hospital wastewater and super fi cial water: Are they genetically related? J Environ Manage. 2011; 92(1): 250-255.

23. Giedrys-kalemba S. Phenotypic and genotypic characteristics of Pseudomonas aeruginosa strains isolated from hospitals in the north-west region of Poland. Pol $\mathrm{J}$ Microbiol. 2006; (May 2014).

24. Bassetti M, Vena A, Croxatto A, Righi E, Guery B. How to manage Pseudomonas aeruginosa infections. Drugs Context. 2018; 7:1-18.

25. Shi HJ, Kim JH, Kim NY, Lee JB, Eom JS. Environmental Culture of Bacteria at the Intensive Care Unit of a Tertiary Hospital in Korea: A Consideration for Improving Medical Environmental Safety and Healthcare-associated Infection. Korean J Heal assoc Infect Control Prev. 2020; 25(2): 105-114.

26. Otchwemah R, Grams V, Tjardes $\mathrm{T}$, Shafizadeh S, Bäthis $H$, Maegele M, et al. Bacterial contamination of open fractures - Pathogens, antibiotic resistances and therapeutic regimes in four hospitals of the trauma network Cologne, Germany. Injury. 2015; 46: S104-S108.

27. Zhu H, Li X, Zheng X. A descriptive study of open fractures contaminated by seawater: Infection, pathogens, and antibiotic resistance. Biomed Res Int. 2017;2017.

28. Gustilo RB, Mendoza RM, Williams DN. Problems in the Management of Type III (Severe) Open Fractures. J Trauma Inj Infect Crit Care. 1984; 24(8):742-746.

29. P Patanwala AE, Radosevich JJ, Meshay I, Naderi M, Culver MA, Lee YG, et al. Cefazolin Monotherapy Versus Cefazolin Plus Aminoglycosides for Antimicrobial Prophylaxis of Type III Open Fractures. Am J Ther. 2019;8:1.

30. Depcinski SC, Nguyen KH, Ender PT. Cefazolin and an aminoglycoside compared with cefazolin alone for the antimicrobial prophylaxis of type III open orthopedic fractures. Int J Crit Illn Inj Sci. 2019;9(3):127-131.

31. Hand TL, Hand EO, Welborn A, Zelle BA. Gram-negative antibiotic coverage in Gustilo-Anderson type-III open fractures. JBJS. 2020 Aug 19;102(16):1468-74. 
32. Aggarwal J, Lustrino J, Stephens J, Morgenstern D, Tang WY. CostMinimization Analysis of Dexmedetomidine Compared to Other Sedatives for Short-Term Sedation During Mechanical Ventilation in the United States. ClinicoEconomics and Outcomes Research: CEOR. 2020;12:389. 